\section{Monika Kavalir, Andrej Stopar}

University of Ljubljana

Slovenia
2015, Vol. 12 (1), 5-8(144)

revije.ff.uni-lj.si/elope

doi: 10.4312/elope.12.1.5-8

\title{
Cultural Encounters with the English-Speaking World
}

The idea for the present volume grew out of a very successful series of summer schools bringing together students and staff from five different countries under the auspices of the Erasmus Intensive Programme "Cultural Landscapes: Negotiating Cultural Encounters with the English-Speaking World." ${ }^{1}$ Focussing on the cultural aspects of the English-speaking world and on intercultural communication, this volume of ELOPE reflects both the main aims of the summer school and the fundamental mission of the journal to promote the research and discussion of linguistic and literary issues.

The papers in the present volume thus span not only different countries and ethnicities but also combine the traditional fields of English Studies - linguistics, literature, teaching and translation. What brings them together is the fact that they all take a close and critical look at the cultural differences and barriers encountered in interaction with English-speaking countries and the specificities of English-mediated intercultural communication. They acknowledge that "any definition of culture is necessarily reductionist" (Sarangi 2009, 87) and that the notion of culture should be seen as dynamic rather than static, internally heterogeneous rather than unified. The concept of Otherness, then, as used in the present volume, implies both blurred boundaries of what constitutes 'us' and 'them', as well as the awareness that "we' are the others' other" (Cerqueira 2013 in Sarmento 2014, 605).

Somewhat in line with Braudel's (1980) classic criteria for the study of social groups, the volume is divided into two parts. The four papers in the first part - "Cross-Cultural Landscapes" - work on identifying individual cultural areas (which may be national, e.g., American, Croatian, British, Irish, Polish, Slovenian, or international, exploring English as a lingua franca) or various loci within their boundaries, including the creation of new pockets of shared culture. When several cultures are involved, this research is cross-cultural, looking at different domains across cultural borders.

Weronika Gasior's paper “Cultural Scripts and the Speech Act of Opinions in Irish English: A Study amongst Irish and Polish University Students" brings a detailed investigation into how opinions are expressed in Irish English by Irish and Polish native speakers. She discerns differences in the cultural scripts for opinions in each culture that reflect linguistic formulas as well as divergent sociopragmatic attitudes and shows the contrast between the Anglo focus on tolerance and the Polish rational approach.

In "House and Home across Cultures," Monika Kavalir chooses the notions of 'house' and 'home' as the starting point of her exploration of various American, British and Slovenian cultural practices and concepts. Her contribution discusses the size of people's dwellings, the use of light, colour and style, hygiene, class distinctions, and their attitudes to house and home. Relying on corpus and

The summer schools were supported by Erasmus IP grants (ERA-IPR 04/11, 08/12, and 17/13) and held in Glasgow (2012), Swansea (2013), and Newcastle upon Tyne (2014). We are immensely grateful that we were able to work together with and learn from the following wonderful colleagues: Sandarenu Kumarasamy and Kathrin Luckmann from the University of DuisburgEssen; Weronika Gasior from the University of Limerick; Lili Cavalheiro and José Duarte from the University of Lisbon; Anamarija Šporčič from the University of Ljubljana; and Ljubica Matek, Jasna Poljak Rehlicki, and Alma Vančura from the University of Osijek. 
statistical data, Kavalir presents the intricacies of the links between language and culture, and shows that language cannot exist outside culture.

In "Developing Intercultural Communicative Competence in ELF Communication," Lili Cavalheiro examines the characteristics of English as a Foreign Language (EFL) and English as a Lingua Franca (ELF) and shows how interactants meet in a new cultural space where the concept of (intercultural) communicative competence (ICC) is an important goal for both frameworks. She provides a succinct but informative exploration of this notion and supplements it with examples of how ICC is reflected in ELF in the use of such strategies as backchanneling, negotiation of meaning, repetition, and self-repair, arguing for more attention to be devoted to developing such skills in all kinds of language pedagogy.

The final article "Teaching Horror Literature in a Multicultural Classroom," by Ljubica Matek, tackles the challenge(s) of discussing horror literature in the classroom. Drawing on some cognitive and emotional benefits of including horror texts in the syllabus, Matek rejects the reservations some teachers have about tackling macabre themes with their students. Moreover, by analysing Mary Shelley's Frankenstein and H. P. Lovecraft's stories, she demonstrates that teaching horror literature can be used as a means of deconstructing our preconceptions of the Other and creating a shared field centred on what is universal rather than different across people.

The second part of the volume - "Intercultural Landscapes" - brings four papers that pay attention primarily to the borrowings of cultural elements across cultural groups and the way this exchange is evaluated. This is intercultural research looking at actual encounters involving "new experiences mediated through new or additional languages and cultures" (Liddicoat and Scarino 2013, 48) and encompassing different linguistic and cultural backgrounds, which can be perceived either positively or negatively.

José Duarte's essay "The Importance of Being 'On the Road': A Reading of the Journey in The Darjeeling Limited (2007) by Wes Anderson" invites us to join the author on the road and experience the cultural and personal landscapes explored in road movies. Duarte provides an overview of the road movie genre, discusses its evolution through decades, and mentions some of its most typical representatives. The focus of his analysis, however, is on an atypical road movie - the film The Darjeeling Limited. He claims that journeys such as the one presented in The Darjeeling Limited matter because they give us the opportunity to learn about ourselves and the Other.

"Us vs. Them: Cultural Encounters in Warzones through Reading American War Literature," the paper by Jasna Poljak Rehlicki, presents the significance of understanding different cultures and civilizations from the military perspective. Drawing on her reading of American novels about the wars in Vietnam and Iraq, she analyses the cultural encounters that the protagonists in her corpus of (non-)fiction works have with their adversaries. Poljak Rehlicki concludes that cultural training aimed at winning a war will rarely help one culture appreciate the other.

What are the main stereotypes Slovenian university students of English have about US Americans? In his article "Encounters with National Stereotypes in Foreign Language Teaching: Adjectives Describing Americans," Andrej Stopar takes as his starting point research done in the USA and adapts it to gauge Slovenian students' reactions, investigating not only which stereotypes are present but also how they differ in their content and (positive/negative) connotations compared to the original studies, thus providing valuable information for ELT pedagogy in Slovenia and ideas for similar undertakings elsewhere. 
Janko Trupej's paper “The 'Negro' in John Steinbeck's Of Mice and Men: A Comparison of Socialist and Post-Socialist Strategies for Translating Racial Elements" discusses John Steinbeck's novel of Mice and Men and its three existing Slovenian translations in the light of racial discourse. Aside from individual translators' choices, the analysis of micro- and macrostructural shifts with regard to racial terms such as 'nigger' and 'negro' shows how social and cultural circumstances, such as a socialist outlook or the relations between the then Yugoslavia and the USA, can influence the style and either suppress or accentuate ideological elements present in a work of literature.

Looking at a number of domains and contexts, the papers included complement each other in interesting ways. Once cross-cultural differences are identified, they will logically be considered as potential sources of problems (or benefits) in intercultural communication, and any investigation into intercultural encounters as shifts in values and affective factors necessarily builds on crosscultural analysis. The two parts of the volume thus form a continuum rather than a dichotomy and the two approaches naturally intertwine. Similarly to other projects exploring intercultural communication (e.g., Culpeper, Crawshaw, and Harrison 2008 or Žegarac and Spencer-Oatey 2013), it can be seen here as well that research into actual cultural encounters informs the theory behind it and vice versa.

Intercultural communication is often linked to miscommunication and it should not be forgotten that, quite apart from theoretical considerations, "it is human beings bearing the whole burden of culture-in-communicating as individuals, who meet, converse, talk, have conflicts, struggle, i.e., communicate in face-to-face interaction" (Hinnenkamp 2009, 186). It is therefore our fervent hope that the insights provided by the authors (helped by a great many reviewers, to whom we offer our sincere thanks) will not only make a difference in the lives of students and staff who participated in the summer school project but will also contribute to the field and benefit the public at large.

Monika Kavalir and Andrej Stopar, University of Ljubljana

Editors of ELOPE Vol. 12, No. 1

\section{References}

Braudel, Fernand. 1980. On History. Chicago: University of Chicago Press.

Culpeper, Jonathan, Robert Crawshaw, and Julia Harrison. 2008. “'Activity Types' and 'Discourse Types': Mediating 'Advice' in Interactions between Foreign Language Assistants and Their Supervisors in Schools in France and England." Multilingua 27:297-324. doi:10.1515/MULTI.2008.015.

Hinnenkamp, Volker. 2009. “Intercultural Communication.” In Culture and Language Use, edited by Gunter Senft, Jan-Ola Östman, and Jef Verschueren, 185-201. Amsterdam: John Benjamins.

Liddicoat, Anthony J., and Angela Scarino. 2013. Intercultural Language Teaching and Learning. Chichester: Wiley-Blackwell.

Sarangi, Srikant. 2009. "Culture.” In Culture and Language Use, edited by Gunter Senft, Jan-Ola Östman, and Jef Verschueren, 81-104. Amsterdam: John Benjamins.

Sarmento, Clara. 2014. "Interculturalism, Multiculturalism, and Intercultural Studies: Questioning Definitions and Repositioning Strategies." Intercultural Pragmatics 11 (4): 603-18. doi:10.1515/ip-2014-0026. 
Žegarac, Vladimir, and Helen Spencer-Oatey. 2013. "Achieving Mutual Understanding in Intercultural Project Partnerships: Cooperation, Self-Orientation, and Fragility." Intercultural Pragmatics 10 (3): 433-58. doi:10.1515/ip-2013-0019. 